\title{
ANALISIS WACANA KRITIS STRATEGI POLITIK PENGGUNAAN BAHASA DALAM PIDATO PRESIDEN SUSILO BAMBANG YUDHOYONO
}

\author{
Endang Sumarti \\ Fakultas Pendidikan Bahasa dan Seni IKIP Budi Utomo Malang \\ e-mail: endangsumarti@yahoo.com
}

\begin{abstract}
This study on the political strategy in the language use in Susilo Bambang Yudhoyono's speeches is focused on the language behaviors. The data were collected from the internet sources containing his speeches in several occasions with regard to political policies during his presidency. The data were analyzed using the critical discourse analysis approach. The results show that his political strategy in the language use is reflected in the uses of words, sentences, and figures of speech. The language use helps public understandings of the conditions that Indonesian people are now facing and supports his presidency. From the language praxis, his political strategy in the language use is relevant to language behaviors in general.
\end{abstract}

Keywords: political strategy, language use, speech

\section{PENDAHULUAN}

Wacana (discourse), dalam telaah ilmu sosial, tidak lagi dimengerti sebagai sarana untuk menyampaikan gagasan atau menjelaskan fenomena natural atau sosial lewat artikulasi kebahasaan, tetapi dimengerti sebagai sarana untuk memproduksi dan mereproduksi makna oleh subjek atas kepentingan tertentu. Pemahaman ini didasarkan kenyataan bahwa makna dalam wacana tidak pernah netral dari kepentingan subjek. Wacana selalu bermuatan makna sesuai dengan "kemauan" subjek walaupun dalam proses pembentukannya "Subjek tidak senantiasa menyadari sepenuhnya atau tidak dalam pengendalian mutlak atas apa yang mereka lakukan". Sebagaimana dikatakan oleh Foucault (1977), "Apa yang bermakna dari sesuatu yang dikatakan orang tidaklah senantiasa tergantung dari apa yang menyistematisasi mereka sejak semula". Oleh karena itu, wacana merupakan kaitan yang rumit antara tanda-tanda dan praksis yang, pada gilirannya, mengatur eksistensi dan reproduksi sosial.

Wacana juga bisa memberikan perbedaan-perbedaan substansial terhadap individu-individu sebagai anggota suatu kelompok, kelas sosial, atau himpunan-himpunan sosial lainnya. Bahkan, wacana bisa berperan sebagai perantara bagi pembentukan rasa kebersamaan sesama anggota dan rasa berbeda dengan kelompok lain. Dalam wacana politik, "kemauan" subjek pada wacana ini lebih terasa. Produksi dan reproduksi makna dalam wacana politik ditentukan oleh kuasa-kuasa yang bermain dalam kehidupan politik pada masanya. Oleh karana itu, wacana politik merupakan "representasi dalam dirinya sendiri dari hubungan-hubungan politis" (Shapiro, 1984:140) dan merupakan ruang bagi penggelaran kuasa-kuasa tertentu. Atas pemahaman demikian, wacana politik amat diwarnai oleh peran yang dimainkan oleh kuasa-kuasa yang ada di dalamnya. Bahkan, secara lebih spesifik, "kuasa dianggap senantiasa berada dalam setiap proses wacana 
dan ia memberikan batasan-batasan tentang apa yang diperkenankan menjadi wacana, perspektif yang mesti dipakai di dalamnya, topik apa yang dibicarakan, dan norma-norma serta elaborasi konsep-konsep dan teori-teori apa yang bisa dan sah untuk dipakai."

Dalam pemerintahan Presiden Susilo Bambang Yudhoyono gambaran teoritis tersebut amat terasa. Sebagai buktinya, bisa dilihat langsung dari pidatonya dalam berbagai macam acara yang berbeda. Dalam pidatonya di berbagai macam acara, Presiden Susilo Bambang Yudhoyono langsung menyampaikan pidato politik yang intinya minta dukungan dan kerjasama seluruh rakyat Indonesia dalam melaksanakan berbagai tugas beratnya serta mengajak masyarakat untuk selalu menjaga persatuan dan kesatuan bangsa.

Pada sisi lain, pemunculan pemerintahan Presiden Susilo Bambang Yudhoyono merupakan presiden pertama yang terpilih dengan menggunakan sistem pemilihan langsung. Hal ini berimplikasi kepada beberapa hal. Pertama, Presiden Susilo Bambang Yudhoyono mendapatkan kadar legitimasi yang lebih tinggi daripada presiden sebelum-sebelumnya karena mendapatkan mandat langsung dari rakyat, yang dalam teori demokrasi merupakan pemegang kekuasaan tertinggi. Kedua, sebagai presiden terpilih yang tentunya ingin terus maju dalam pemilu selanjutnya, penjagaan citra adalah sesuatu yang sangat penting mengingat dengan sistem pemilihan langsung ini penilaian masyarakat sangat berperan dalam menentukan apakah ia akan terus memegang tampuk kepemimpinan atau tidak. Mekanisme reward and punishment yang langsung berada di tangan masyarakat membuat pencitraan ini menjadi salah satu hal yang krusial. Enam puluh satu persen suara menghantarkan Susilo Bambang Yudhoyono sebagai seorang
Presiden Republik Indonesia. Pembentukan citra ini berkaitan dengan dua hal, yaitu bagaimana strategi komunikasi politik yang diterapkan oleh Presiden Susilo Bambang Yudhoyono dan juga bagaimana kinerja pemerintahan yang berada dibawahnya.

Dalam hal strategi komunikasi politik yang dijalankan, Presiden Susilo Bambang Yudhoyono patut mendapatkan acungan jempol. Kedekatannya dengan media massa memungkinkan ia untuk mengkomunikasikan segala kebijakannya dengan masyarakat. Belum lagi deretan juru bicaranya yang mumpuni. Keberaniannya untuk memindahkan sementara pusat pemerintahan ke DIY dan menginap di barak penampungan pengungsi merupakan dua contoh bagaimana ia mencoba membangun imejnya sebagai seorang presiden yang senantiasa peduli dan dekat dengan rakyatnya baik dikala suka maupun duka.

Di sisi kinerja kepemimpinanya, Ia telah membuat banyak sekali kebijakan baik yang positif maupun negatif. Dalam bidang ekonomi, kebijakannya menaikan harga BBM, oleh banyak orang dianggap sebagai sebuah kebijakan yang tidak populis dan diperkirakan dapat menjatuhkan citra Presiden Susilo Bambang Yudhoyono di mata masyarakat. Bukan hanya karena kenaikan BBM sendiri, tetapi imbasnya terhadap sektor lain dirasakan sangat menyiksa masyarakat. Kenaikan harga kebutuhan pokok, transportasi, Tarif Dasar Listrik dan lain-lain merupakan sedikit dari sekian banyak dampak yang disebabkan naiknya harga BBM.

Tetapi, kinerja yang negatif di bidang ekonomi ini diimbangi dengan kinerja yang cukup positif dalam bidang politik, hukum dan beberapa bidang lainnya. Di bidang politik, keberhasilannya mengadakan perdamaian dengan Gerakan Aceh Merdeka (GAM) diang- 
gap sebagai sebuah kesuksesan tersendiri. Bahkan karena hal ini, apresiasi bukan hanya datang dari dalam negeri. Komite Nobel menghadiahi Presiden Susilo Bambang Yudhoyono sebagai salah satu kandidat penerima penghargaan Nobel perdamaian. Dibidang penegakan hukum, Presiden Susilo Bambang Yudhoyono dapat dikatakan sebagai seorang cukup memegang komitmen dalam memerangi korupsi, permasalahan klasik yang menghantui negeri ini. Tidak seperti presiden-presiden sebelumnya yang dianggap penanganan korupsinya jalan ditempat, di era Presiden Susilo Bambang Yudhoyono secercah harapan mulai tampak melihat giatnya KPK memburu koruptor-koruptor yang merugikan negara ini.

Melihat pertimbangan-pertimbangan di atas, lantas wajar jika masyarakat saat ini tetap memberikan apresiasi yang cukup baik terhadap Presiden Susilo Bambang Yudhoyono. Oleh karena itu, perbaikan di bidang ekonomi merupakan suatu hal yang mau tidak mau harus segera dilakukan oleh Presiden Susilo Bambang Yudhoyono. Hal ini karena bidang inilah yang langsung menyentuh kehidupan masyarakat. Sebuah langkah baik telah dilakukan oleh pemerintahan Presiden Susilo Bambang Yudhoyono, percepatan pelunasan hutang yang sudah dilakukan merupakan awal yang baik untuk menumbuhkan kepercayaan investor kepada Indonesia.

Pada sisi lain, pemunculan pemerintahan Presiden Susilo Bambang Yudhoyono yang berbarengan dengan banyaknya bencana yang terus melanda tanah air ini, merupakan ujian bagi Presiden Susilo Bambang Yudhoyono dalam melakukan pola kepemimpinannya. Keadaan ini tentu berdampak pada kondisi kehidupan politiknya, termasuk tindakan komunikasi politiknya. Kondisi ini tentu membuat upaya lebih getol
Presiden Susilo Bambang Yudhoyono untuk segera mendapatkan legitimasi dan kepercayaan dari sebagian besar rakyat dan kepercayaan dari sebagian besar rakyat dan dalam rangka konsolidasi serta memantapkan kedudukan dan kekuasaannya baik berupan tuturan (speech) maupun tindakan (action). Dari kedua upaya tersebut yang paling segera bisa dilakukan adalah penciptaan makna dalam wacana politik. Sebab, dengan penerapan wacana politik yang jitu, gagasan atau makna yang disampaikan oleh Presiden Susilo Bambang Yudhoyono bisa dipahami rakyat atau publik sesuai dengan yang diinginkannya. Sebaliknya apabila penciptaan makna dalam wacana politik yang diterapkannya ternyata kurang atau tidak dipahami oleh rakyat, bahkan ditentangnya, rakyat akan membuat kontraproduksi makna pada konteks yang sama.

Bedasarkan paparan di atas, kajian analisis ini hanya membatasi pada "Strategi Politik Penggunaan Bahasa dalam Pidato Presiden Susilo Bambang Yudhoyono. Dengan kajian ini akan diperoleh "profil kebahasaan" wacana politik Presiden Susilo Bambang Yudhoyono, dalam tataran struktur mikro. Selain itu, struktur makro yang lebih melibatkan konteks, proses produksi, dan kebermaknaan juga dianalisis, dengan pertimbangan bahwa pada kenyataannya sosok wacana tidak hanya terdiri dari aspek kebahasaan, tetapi juga bagaimana proses pemunculannya dan ideologi apa yang ada dibaliknya.

Analisis wacana kritis memandang bahasa sebagai suatu bentuk praktik sosial. Kajian analisis wacana kritis berusaha untuk membuat manusia sadar akan pengaruh timbal balik antara bahasa dan struktur sosial yang dalam kehidupan nyata sering tidak disadari. Remlinger (http://www.linguistik-online.de/helfl 99/remlinger.hatm) menyatakan bahwa tujuan analisis wacana 
kritis adalah untuk memberi penilaian terhadap produksi, struktur internal, dan keseluruhan organisasi teks. Analisis wacana kritis lebih meng-utamakan pembahasan pada tujuan politis dalam bentuk teks, proses memproduksi teks, dan proses memahami struktur kekuasaan yang muncul dari teks tersebut.

Analisis wacana kritis melihat wacana penggunaan bahasa dalam tuturan dan tulisan sebagai suatu bentuk praktik sosial. Pendeskripsian wacana sebagai praktik sosial mengimplikasikan sebuah hubungan dialektis antara peristiwa wacana khusus dengan situasi, isntitusi, dan struktur sosial yang melatarinya. Yang dimaksud dengan hubungan dialektis di sini adalah hubungan dua hal yaitu peristiwa kewacanaan dibentuk dan membentuk situasi, institusi, dan struktur sosial.

Model analisis wacana yang dipakai oleh Van Dijk ini sering disebut sebagai "kognisi sosial". Hal ini ada kaitannya dengan pendekatan yang digunakan oleh Van Dijk. Menurut Van Dijk, penelitian atas wacana tidak cukup hanya didasarkan pada analisis tekstual, tetapi juga hubungan antara struktur teks dan percakapan dengan konteks kognitif, sosial, kultural, atau historis. Di samping itu, proses pemroduksian dan pemahaman teks, interaksi antarpengguna bahasa, dan fungsi sosial dan kultural wacana perlu dijadikan sebagai objek kajian. Hal itu terjadi karena teks hanya merupakan hasil suatu praktik produksi. Oleh sebab itu, dalam analisis wacana, harus dianalisis juga proses produksi teks sehingga diperoleh pengetahuan tentang faktor-faktor yang melatarbelakangi lahirnya teks. Sebagai contoh, jika ada teks yang memarjinalkan kedudukan wanita, maka dibutuhkan penelitian tentang proses produksi teks tersebut sehingga diketahui latar belakang pemarjinalan wanita dalam teks. Misalnya, pemarjinalan wanita itu terjadi karena kesadaran mental di antara penutur, bahkan kesadaran masyarakat yang memandang wanita secara rendah. Dengan demikian, proses analisis wacana melibatkan proses kognisi sosial, yang sebenarnya diadopsi dari bidang psikologi sosial.

Van Dijk membuat suatu jembatan yang menghubungkan elemen besar berupa struktur sosial dengan elemen wacana yang mikro dengan sebuah dimensi kognisi sosial. Kognisi sosial tersebut memiliki dua arti. Disatu sisi, ia menunjukkan bagaimana proses produksi teks oleh penulis. Di sisi lain, ia menggambarkan bagaimana nilai-nilai masyarakat menyebar dan diserap oleh penulis yang akhirnya digunakan untuk memproduksi teks tersebut (1997:144180). Van Dijk menggambarkan model analisis wacana tersebut melalui beberapa analisis pemberitaan di media. Titik perhatian Van Dijk terutama pada studi mengenai rasialisme. Dari berbagai kasus, Van Dijk terutama menganalisis bagaimana wacana di media turut memperkuat rasialisme yang ada dalam masyarakat.

Sementara itu Norman Fairclough membangun suatu model mengintegrasikan analisis wacana yang didasarkan pada linguistik dan pemikiran sosial politik, dan secara umum diintegrasikan pada perubahan sosial. Oleh karena itu, model yang dikemukakan Fairclough sering juga disebut sebagai model perubahan sosial. Pengertian wacana menurut Fairclough lebih mengarah pada pemakaian bahasa sebagai praktik sosial yang berimplikasi sebagai berikut. Pertama, wacana adalah bentuk tindakan, seseorang menggunakan bahasa sebagai suatu tindakan pada dunia dan khususnya sebagai bentuk representasi ketika melihat dunia/realitas. Pandangan semacam ini tentu saja menolak pandangan bahasa sebagai term individu. Kedua, model mengimplikasikan 
adanya hubungan timbal balik antara wacana dan struktur sosial. Di sini wacana terbagi oleh struktur sosial, kelas, dan relasi sosial yang dihubungkan dengan relasi spesifik dari institusi tertentu seperti pada hukum atau pendidikan, sistem dan klasifikasi.

Fenomena penciptaan makna dalam wacana politik bisa disiasati lewat analisis wacana yang dikembangkan oleh Van Dijk (1985), yang dalam prakteknya memanfaatkan studi linguistik, terutama ketika menganalisis aspek tekstualnya. Hal ini menampak pada saat menganalisis unit kebahasaan pada tataran leksikal, sintaksis, dan gaya penyampaiaan sebagai bagian dari struktur mikro. Tetapi pada saat menganalisis konteks, proses produksi, dan kebermaknaan, analisis wacana memandang teks sebagai bagian dari struktur makro. Pandangan ini didasarkan pada kenyataan bahwa sosok wacana tidak hanya terdiri dari aspek kebahasaan, tetapi juga bagaimana proses pemunculannya dan ideologi apa yang ada dibaliknya (Fairclough, 1995:54;1998).

Penerapan elemen-elemen kebahasaan dalam "teks" ini dipahami oleh Van Dijk sebagai bagian dari strategi berkomunikasi yang berkaitan erat dengan politik. Pemilihan kata tertentu, penyusunan kata tertentu, dan pemakaian gaya bahasa tertentu, bukan hanya dipandang sebagai politik berkomunikasi, tetapi juga harus dipandang sebagai politik berkomunikasi. Setiap praktek berkomunikasi juga dapat dipahami sebagai praktek manajemen kesan untuk membangun kesan positif dan menutupi realitas negatif atau kesan apapun yang diinginkan komunikator dimata komunikan. Sebab, penerapan elemen-elemen kebahasaan tersebut oleh komunikator, selain dimaksudkan agar idenya dipahami oleh komunikan, juga dimaksudkan agar bisa menciptakan opini, menciptakan dukungan, memperoleh legiti- masi, dan bahkan melibas lawan.

\section{METODE}

Studi tentang strategi politik penggunaan bahasa dalam pidato Presiden Susilo Bambang Yudhoyono ini memfokuskan pada perilaku kebahasaan Susilo Bambang Yudhoyono yang tertuang dalam pidatonya ketika menjabat sebagai presiden. Namun demikian tidak semua naskah pidato Presiden Susilo Bambang Yudhoyono dianalisis dalam kajian ini. Adapun naskah pidato Presiden Susilo Bambang Yudhoyono yang dianalisis dalam kajian ini ada 5 buah. Pengambilan naskah pidato tersebut dilakukan secara acak, yakni naskah pidato tahun 2006, 2007, dan 2008. Studi ini berorientasi pada verbal approach bukan behavioral approach. Ini berarti bahwa hanya ungkapan-ungkapan verbal dalam komunikasi kebahasaan dalam wacana pidato saja yang menjadi titik perhatian kajian ini. Jika aspek perilaku nonkebahasaan 'terpaksa" dibicarakan hal ini sematamata karena pertimbangan konteks yang merupakan hallo effect dari wacana politik yang dikaji.

Dengan demikian, data studi ini berupa serangkaian fenomena kebahasaan dalam wacana politik yang disampaikan oleh Presiden Susilo Bambang Yudhoyono dalam berbagai pidato pada masa pemerintahannya. Wacana politik yang dimaksud berupa ungkapan-ungkapan verbal dalam berbagai tema dan kasus baik dalam bidang pertahanan dan keamanan, hukum dan keadilan perekonomian (keuangan dan perpajakan), kesejahteraan sosial, maupun pelayanan publik. Dalam realitasnya, serangkaian ungkapan-ungkapan verbal dalam wacana pidato politik tersebut disosialisasaikan dan dipublikasikan di media massa, baik media cetak maupun elektronik. Oleh karena itu, publik (atau rakyat) pun pada dasarnya selalu berpeluang untuk mengetahui 
dan (akhirnya) memaknainya.

Karena bersumber pada media massa, dalam hal ini internet, data dalam studi ini berjenis dokumenter. Data ini didapat dari media massa yaitu internet, yang memuat pidato-pidato dan/atau pernyataan Presiden Susilo Bambang Yudhoyono dalam berbagai kesempatan yang menyangkut kebijakan-kebijakan politiknya selama pemerintahan berlangsung. Data-data tersebut diakumulasikan secara komprehensif, sehingga merupakan data yang saling melengkapi (komplementer).

\section{HASIL DAN PEMBAHASAN Pemakaian Kata}

Dalam tataran pemakaian kata, unsur yang tampak pada wacana pidato Presiden Susilo Bambang Yudhoyono adalah pemakaian kata-kata persona, pemakaian kata yang bernuansa "keterbukaan", dan pemakaian kata yang bernuansa "reformasi". Ketiga hal yang hampir menyebar ke semua wacana pidato Presiden Susilo Bambang Yudhoyono ini dipakai dengan maksud dan tujuan yang berbeda.

\section{Pemakaian Kata Persona.}

Kata persona dipakai Presiden Susilo Bambang Yudhoyono sebagai alat untuk menunjukkan posisinya dalam wacana pidato yang dibangunnya. Dari data verbal yang terkumpul, Presiden Susilo Bambang Yudhoyono menggunakan kata persona (a) saya, (b)kami, (c) kita, (d) pemerintah, (e) bangsa Indonesia, dan (f) Indonesia.

Kata persona saya dipakai Presiden Susilo Bambang Yudhoyono ketika menyampaikan harapan, keinginan, ajakan, pertimbangan, dan sikap yang ditujukan kepada publik. Selain itu, penggunaan kata persona saya lebih bermakna penonjolan diri, dibandingkan dengan penggunaan kata persona yang lain. Pemakaian kata persona saya hanya berkaitan dengan tema atau topik yang sudah dimaklumi oleh publik dan tidak kontroversial, atau tema dan topik yang menjadi isu sentral, yang memerlukan pemecahan. Contoh berikut menunjukkan pemakaian kata tersebut.

"Saya berterima kasih, pembicaraan saya dengan para pemimpin, pembicaraan isteri saya dengan mitranya di sini, mereka memberikan pujian terhadap tenaga kerja Indonesia yang bekerja di sini. Baik itu yang professional, yang skill workers, maupun yang semi skill workers, maupun saudara kita yang bekerja pada tingkat yang lebih rendah. Atas nama negara, pemerintah dan rakyat, saya mengucapkan terima kasih dan penghargaan kepada saudara semua". (Sambutan Presiden, 2 Mei 2006).

"Saya menyadari, bahwa konsekuensi sikap tegas itu, telah menyebabkan rasa kekhawatiran, dan bahkan rasa ketakutan yang berlebihan di sebagian kalangan pengambil keputusan dan aparatur pelaksana di lapangan. Saya ingin menegaskan, bahwa kekhawatiran dan ketakutan itu tidak perlu ada, sepanjang semua tindakan dilakukan sesuai prosedur dan ketentuan-ketentuan yang berlaku. Di sisi lain, aparat penegak hukum wajib untuk bersikap hatihati dalam menerima dan mempelajari setiap laporan, agar jangan salah bertindak". (Pidato Kenegaraan, 16 Agustus 2006)

"Saya merasa bersyukur bahwa dalam setahun belakangan ini, koordinasi antara Pemerintah Pusat dengan Pemerintah Daerah telah berjalan semakin baik. Saya telah berulangkali menyelenggarakan sidang kabinet, yang ikut dihadiri oleh para 
gubernur dari semua provinsi. Dalam rapat-rapat itu, kami bahas berbagai permasalahan pembangunan nasional dan pembangunan di daerah, yang menjadi tanggung jawab bersama. Dalam berbagai kesempatan, saya juga telah mengundang para bupati dan walikota, bahkan Ketua DPRD Kabupaten dan Kota, dari seluruh Tanah Air, untuk menyamakan visi dan misi kita dalam melaksanakan pembangunan. Dengan koordinasi yang makin baik, saya yakin berbagai permasalahan yang ada akan dapat kita tanggulangi secara bersama". (Keterangan Pemerintah, 23 Agustus 2006).

"Kini tibalah saya pada bagian akhir dari Keterangan Pemerintah yang saya sampaikan. Dalam bagian akhir ini, saya ingin menegaskan kembali komitmen saya untuk memberantas korupsi. Selama saya menjalankan roda pemerintahan, saya telah memberikan persetujuan pemeriksaan terhadap 7 Gubernur, 63 Bupati/Wakil Bupati, dan Walikota/Wakil Walikota". (Keterangan Pemerintah, 23 Agustus 2006).

Berbeda dengan saya, pemakaian kata persona kami lebih mengarah kepada makna kelompok atau lembaga. Kata persona kami dipakai Presiden Susilo Bambang Yudhoyono ketika menyampaikan rencana, janji, peringatan, keyakinan, dan himbauan kepada publik. Apabila ungkapan itu ditujukan kepada rakyat, kata persona kami berarti (aparat) pemerintah. Tetapi, apabila ungkapan itu ditujukan kepada pihak luar (misalnya orang asing, negara lain), kata persona kami berarti bangsa Indonesia atau warga negara Indonesia.

"Alhamdulillah sampai hari ini, yang menjadi tujuan kunjungan kami, agenda kami dapat kita ca- pai dengan baik. Semua pemimpin negara-negara yang saya kunjungi bersepakat bahwa kita ingin meningkatkan secara lebih konkret persahabatan dan kerja sama itu, di banyak bidang, antara lain di bidang investasi, perdagangan, energi, pendidikan, ketenagakerjaan dan lain-lain". (Sambutan Presiden, 2 Mei 2006).

"Setelah kunjungan ini, di Jakarta akan kami rumuskan apa berbuat apa, apa saja yang akan kita tindaklanjuti, timeline-nya seperti apa, kemudian akan kita komunikasikan kembali ke negeri ini, dan kemudiian Insya Allah dapat kita wujudkan sesuai dengan rencana dan kesepakatan yang telah kita tetapkan". (Sambutan Presiden, 2 Mei 2006).

"Pemerintah telah memetik banyak manfaat dari berbagai masukan, saran, dan kritik yang konstruktif yang disampaikan Dewan, baik secara kelembagaan, maupun secara perorangan anggotanya. Semua masukan, saran, dan kritik itu, kami tampung dan kami olah, sebagai bahan dalam memperbaiki dan menyempurnakan berbagai kebijakan yang kami tempuh". (Keterangan Pemerintah, 23 Agustus 2006).

"Dalam rapat-rapat itu, kami bahas berbagai permasalahan pembangunan nasional dan pembangunan di daerah, yang menjadi tanggung jawab bersama". (Keterangan Pemerintah, 23 Agustus 2006).

Kata persona kita dipakai Presiden Susilo Bambang Yudhoyono ketika menyampaikan kepercayaan, rencana, suasana hati, harapan, ajakan, seruan, dan sikap. Hanya saja, ada perbedaan posisi antara pemakaian kata persona kita dan kata persona sebelumnya (saya 
dan kami). Apabila dalam pemakaian kata persona saya dan kami terlihat jelas posisi dikotomis antara Presiden Susilo Bambang Yudhoyono dan rakyat, dalam pemakaian kata persona kita tidak terlihat posisi dikotomis itu. Dengan menggunakan kata persona kita, Presiden Susilo Bambang Yudhoyono bermaksud menciptakan komunitas antara dia (sebagai pengungkap wacana) dan rakyat (sebagai penerima wacana). Dengan demikian, apa yang menjadi gagasan Presiden Susilo Bambang Yudhoyono dalam ungkapan wacananya juga menjadi gagasan rakyatnya. Apa yang menjadi kepercayaan, rencana, suasana hati, harapan, ajakan, seruan, dan sikap Presiden Susilo Bambang Yudhoyono, juga menjadi kepercayaan, rencana, suasana hati, harapan, ajakan, seruan dan sikap rakyatnya. Kutipan berikut menunjukkan ungkapan itu.

"Kita tidak bermaksud untuk memperbesar kekuatan yang sudah ada. Yang hendak kita bangun adalah kekuatan esensial, yang kita anggap cukup tangguh dan mampu untuk mengamankan seluruh wilayah kedaulatan negara kita. Fokus perhatian pertahanan $k i t a, k i t a$ arahkan untuk menjaga kawasan perbatasan laut dan darat, terutama pulau-pulau terluar dan terdepan, termasuk membangun pos-pos pengamanan TNI".(Pidato Kenegaraan, 16 Agustus 2006).

"Tidak ada suatu bangsa yang menjadi bangsa yang jaya, tanpa ujian. Upaya memecah-belah persatuan bangsa telah beberapa kali terjadi, namun semua itu berhasil kita atasi. Krisis demi krisis telah datang silih berganti dalam perjalanan sejarah kita, namun semua itu dapat kita selesaikan. Kita meyakini, bahwa susunan dan bentuk Negara Kesa- tuan Republik Indonesia yang berdasarkan Pancasila adalah pilihan tepat dan final. Atas ketetapan dan pilihan kita itu, kita harus terus membangun negara, menuju keadaan yang aman dan damai, adil dan demokratis, serta sejahtera, yang menjadi cita-cita dan tujuan kemerdekaan bangsa kita. Kemiskinan dan keterbelakangan harus kita perangi. Konflik dan permusuhan harus kita akhiri. Keadilan dan kesejahteraan harus terus kita tingkatkan. Rasa aman dan damai harus kita mantapkan. Kita patut bersyukur, bahwa dalam setahun belakangan ini, ancaman dan gangguan keamanan di berbagai wilayah telah mereda". (Pidato Kenegaraan, 16 Agustus 2006).

"Aksi-aksi terorisme yang beberapa tahun lalu sangat menggelisahkan masyarakat, telah dapat kita atasi. Kita telah semakin berhasil mencegah dan menanggulangi aksiaksi teror di negara kita. Kepercayaan masyarakat kepada aparat keamanan dan aparat penegak hukum juga semakin tinggi. Kita patut memberikan penghargaan kepada jajaran Polri dan pihak-pihak lain yang telah berhasil menanggulangi ancaman terorisme ini. Sebagaimana sering saya sampaikan, kedepan, kita tidak boleh hanya menangani terorisme yang berada di permukaan, tetapi harus harus kita sentuh dan atasi akar penyebabnya, seperti keterbelakangan, kemiskinan, ketidakadilan, ekstrimitas, radikalitas dan budaya kekerasan. Kita sungguh serius untuk mencegah dan menanggulangi terorisme ini, karena kita ingin menyelamatkan masyarakat dan bangsa kita, menghadirkan keamanan dan ketentraman di negeri kita, dan sekaligus sebagai tanggung jawab dan kebersamaan kita dengan masyara- 
kat global untuk menciptakan dunia yang aman dan damai". (Pidato Presiden, 16 Agustus 2007).

"Dalam penerapan politik luar negeri, kita terus membangun kemitraan melalui diplomasi total. Tahun-tahun terakhir ini kita telah mengembangkan dan meningkatkan kemitraan dengan banyak negara, dengan tujuan untuk menunjang terpenuhinya kepentingan nasional kita. Dengan kerangka kemitraan strategis ataupun kemitraan komprehensif, kita telah meningkatkan kerjasama dan kemitraan kita dengan banyak negara, antara lain Korea Selatan, Republik Rakyat Tiongkok, Australia, Rusia, Jepang dan India". (Pidato Presiden, 16 Agustus 2007).

"Kita juga berhasil menjaga keutuhan negara, dari berbagai ancaman separatisme. Kita berhasil mempersatukan kembali Irian Barat. Kita berhasil menyelamatkan ideologi Negara Pancasila. Kita berhasil keluar dari krisis moneter yang sangat berat, yang melahirkan era "reformasi". Kita berhasil, dengan penuh perjuangan, membangun dan menghadirkan demokrasi, yang mengedepankan kedaulatan rakyat. Kita berhasil menangani dampak bencana tsunami yang maha dahsyat, dan bahkan kemudian menciptakan perdamaian Aceh yang telah bergolak selama lebih dari 30 tahun". (Sambutan Presiden, 20 Mei 2008).

Kata persona bangsa Indonesia dipakai Susilo Bambang Yudhoyono untuk maksud yang sama dengan kita. Sebab, makna yang diacu oleh kata persona kita adalah "bangsa Indonesia". Hanya saja, pemakaian kata persona bangsa Indonesia lebih fleksibel karena ungkapan wacananya selain bisa ditujukan kepada rakyat Indonesia sendiri (sebagai pihak dalam) juga ditujukan kepada pihak luar (orang asing atau negara lain). Fleksibelitas ini tidak dimiliki oleh kata persona kita. Berikut ini contohnya.

"Alhamdulillah, mudah-mudahan ini bisa kita terus wujudkan dan tingkatkan untuk kebaikan kedua bangsa, bangsa Indonesia dengan negara-negara sahabat kita di kawasan ini". (Sambutan Presiden, 2 Mei 2006).

"Bangsa Indonesia dapat berdiri tegak karena, kita mempunyai semangat perjuangan yang tinggi". (Sambutan Presiden, 20 Mei 2008).

Selain menggunakan kata bangsa Indonesia, Presiden Susilo Bambang Yudhoyono pun menggunakan kata persona Indonesia untuk makna yang sama. Oleh karena itu, distribusi pemakaiannya pun relatif sama dengan kata persona bangsa Indonesia. Hanya saja, kata persona Indonesia jarang dipakai oleh Presiden Susilo Bambang Yudhoyono. Penggunakan kata persona tersebut sebagaimana kutipan berikut.

"Sebagai anggota tidak tetap keamanan PBB, Indonesia akan tetap memainkan peran yang konstruktif, berdasarakan politik bebas dan aktif yang kita anut, agar perdamaian dan keamanan dunia semakin dapat ditegakkan. Pada prinsipnya Indonesia berpendapat dan menyerukan untuk digunakannya cara-cara damai, dan bukan militer, dalam penyelesaian berbagai isu dan konflik global, termasuk isu nuklir Iran, nuklir Korea Utara dan isu-isu kritikal lainnya". (Pidato Presiden, 16 Agustus 2007)

Kata persona pemerintah dipakai 
Presiden Susilo Bambang Yudhoyono ketika menyampaikan rencana, sikap, seruan, dan harapan. Berbeda dengan kata persona yang lain, kata persona pemerintah dipakai oleh Presiden Susilo Bambang Yudhoyono berkaitan dengan dengan hukum dan ketatanegaraan serta pelayanan publik, termasuk perlindungannya. Oleh karena itu, dengan menggunakan kata persona pemerintah ini Susilo Bambang Yudhoyono bermaksud mendudukkan diri sebagai bagian dari pihak yang bertanggungjawab atas terselenggaranya pemerintahan yang bersih, terciptanya supremasi hukum, terlindunginya rakyat dari ancaman, terhentinya pelanggaran HAM, dan lain-lain yang menjadi kewajiban pemerintah.

"Dalam kaitan pemberian insentif, pemerintah akan segera mengeluarkan Peraturan Pemerintah untuk mendorong investasi, melalui pemberian fasilitas perpajakan bagi sektor tertentu dan daerah tertentu. Pemerintah juga sedang merampungkan fasilitas pembebasan PPN bagi produk pertanian primer, agar memiliki daya saing yang makin kuat. Dalam rangka meningkatkan daya saing produk-produk industri andalan di dalam negeri, Pemerintah telah melakukan upaya penyederhanaan prosedur dan fasilitas ekspor dan impor, serta harmonisasi tarif bea masuk, sehingga memiliki struktur tarif dan prosedur yang sederhana, harmonis, rendah, dan seragam pada tahun 2010". (Pidato Kenegaraan, 16 Agustus 2006).

"Menyadari adanya berbagai hambatan dalam pelaksanaan desentralisasi fiskal, Pemerintah memandang perlu untuk menyusun kebijakan komprehensif yang bersifat operasional, agar desentralisasi itu dapat kita wujudkan. Berkaitan dengan hal itu, Pemerintah telah merumuskan Rencana Aksi Nasional Desentralisasi Fiskal yang disingkat RANDF, untuk kurun waktu tahun 2005-2009". (Keterangan Pemerintah, 23 Agustus 2006).

"Sebagai contoh dalam penanganan lumpur di Sidoarjo, sejak awal telah kita upayakan. Pemerintah tidak tinggal diam. Pemerintah telah membentuk Badan Pelaksana Penanggulangan Lumpur Sidoarjo (BP2LS). Kita tidak dapat membiarkan rakyat terus menderita. Kita harus secepatnya meringankan penderitaan rakyat dengan penuh kesungguhan. Pemerintah menaruh perhatian yang sungguh-sungguh terhadap masalah ini". (Pidato Presiden, 16 Agustus 2007).

"Terkait dengan isu-isu global, Pemerintah menaruh perhatian yang sangat besar terhadap masalah lingkungan hidup terutama pergantian iklim yang menyebabkan pemanasan bumi". (Pidato Presiden, 16 Agustus 2007).

\section{Pemakaian Kata Bernuansa "Reforma- si"}

Kedudukan Presiden Susilo Bambang Yudhoyono sebagai presiden yang berbarengan dengan bangkitnya era reformasi menghendaki perhatian yang ekstra terhadap aspirasi rakyatnya. Apalagi, pada era ini tuntutan rakyat cenderung kebablasan, sehingga posisi terkesan "serba salah". Untuk mengantisipasinya, berupaya menciptakan strategi politik yang bisa mendukung aspirasi rakyat dalam bentuk ungkapan atau pemakaian kata yang bernuansa reformasi. Oleh Presiden Susilo Bambang Yudhoyono, ungkapan yang bernuansa 
reformasi ini diarahkan pada sikap dan tindakan Presiden Susilo Bambang Yudhoyono yang dianggap sesuai dengan tuntutan reformasi yang dikehendaki rakyat. Kutipan berikut membuktikannya.

"Oleh karena itu, untuk meningkatkan kinerja birokrasi dan menciptakan tata kelola yang bersih dan baik (good and clean governance) pemerintah melaksanakan reformasi birokrasi secara bertahap dan terencana. Reformasi birokrasi, mencakup perbaikan yang seimbang antara sistem kerja, pengukuran kinerja, dan penerapan disiplin dan remunerasi. Beberapa langkah awal reformasi birokrasi ini telah dimulai oleh Departemen Keuangan, Kementerian Negara Pendayagunaan Aparatur Negara, Mahkamah Agung dan Badan Pemeriksa Keuangan". (Pidato Presiden, 16 Agustus 2007).

"Marilah kita lanjutkan reformasi, untuk terus mengembangkan demokrasi, menegakkan hukum, membangun sistem yang bersih, menggiatkan pembangunan daerah, dan meningkatkan ekonomi dan kesejahteraan rakyat". (Sambutan Presiden, 20 Mei 2008).

\section{Pemakaian Kata Bernuansa "Keterbu- kaan"}

Apabila pemakaian kata yang bernuansa "reformasi" diarahkan pada sikap dan tindakan Presiden Susilo Bambang Yudhoyono berkaitan dengan tuntutan reformasi yang sesuai dengan aspirasi rakyat, pemakaian kaya yang bernuansa "keterbukaan" diarahkan pada sikap dan tindakan Presiden Susilo Bambang Yudhoyono yang dianggap bisa mendukung proses reformasi dan pemerintahannya. Hal ini didasarkan atas adanya kesadaran Presiden Susilo
Bambang Yudhoyono bahwa tuntutan reformasi mempersyaratkan adanya keterbukaan di semua pihak. Sebab, hanya lewat suasana keterbukaan inilah aspirasi rakyat bisa tersalurkan secara maksimal.

Kesadaran atas perlunya keterbukaan ini nampak pada pemakaian kata dalam wacana pidato yang diungkapkan Presiden Susilo Bambang Yudhoyono. Dengan penggunaan kata yang bernuansa keterbukaan ini dimaksudkan agar rakyat tahu dan sadar bahwa ia sebagai sosok yang sedang berkuasa pun bersikap dan bertindak terbuka. Dengan demikian, ada kesesuaian dengan yang dikehendaki rakyat selama ini. Upayaupaya Presiden Susilo Bambang Yu dhoyono ini terlihat pada ungkapannya berikut ini.

"Pemerintah telah memetik banyak manfaat dari berbagai masukan, saran, dan kritik yang konstruktif yang disampaikan Dewan, baik secara kelembagaan, maupun secara perorangan anggotanya. Semua masukan, saran, dan kritik itu, kami tampung dan kami olah, sebagai bahan dalam memperbaiki dan menyempurnakan berbagai kebijakan yang kami tempuh". (Keterangan Pemerintah, 23 Agustus 2006).

"Pemerintah selalu terbuka untuk bekerjasama lebih baik. Termasuk membuka diri bagi munculnya gagasan-gagasan baru, untuk penyempurnaan tata hubungan kelembagaan kita". (Pidato Presiden, 16 Agustus 2007).

\section{Pemakaian Kalimat}

Wacana verbal yang diungkapkan Presiden Susilo Bambang Yudhoyono diekspresikan dalam bentuk rangkaian kalimat. Dari segi maksudnya, kalimatkalimat yang diekspresikan Presiden 
Susilo Bambang Yudhoyono ada yang berbentuk (a) kalimat ajakan, (b) kalimat seruan, (c) kalimat harapan, (d) kalimat janji, dan (e) kalimat pernyataan. Pemakaian berbagai jenis maksud kalimat ini disesuaikan dengan tujuan yang ingin dicapai dan jenis isu atau tema yang dilontarkannya.

\section{Pemakaian Kalimat Ajakan}

Kalimat ajakan dipakai Presiden Susilo Bambang Yudhoyono ketika bermaksud ingin melibatkan rakyat baik dalam bentuk tindakan, pikiran, maupun sikap. Oleh karena itu, nuansa yang segera bisa ditangkap dari kalimat ajakan ini adalah kebersamaan. Dengan kalimat ajakan ini, Susilo Bambang Yudhoyono bermaksud menghilangkan jarak antara dia (sebagai penguasa) dan rakyatnya. Oleh karena itu, rumusan kalimat ajakan ini tidak terasa memaksakan kehendak. Sebaliknya yang dituntut adalah kesadaran. Konsekuensinya, agar ajakannya ini diterima oleh rakyat, kalimat ajakan ini bisa diawali atau diikuti dengan rasionalisasi atau penalaran yang disesuaikan dengan pola pikir rakyat. Kutipan berikut membuktikan ungkapan itu.

"Marilah kita tetap tegar, percaya diri, dan bekerja lebih keras lagi untuk mencapai cita-cita kita. Saatnya telah tiba, untuk kita lebih bersatu, bangkit dan melangkah maju. Di depan kita, tersedia banyak kesempatan dan peluang, yang harus kita jemput dan dapatkan. Kepada seluruh pemimpin di Tanah Air, saya mengajak, marilah kita curahkan pikiran, waktu dan tenaga kita untuk meningkatkan kesejahteraan dan kemajuan seluruh rakyat Indonesia, rakyat yang kita cintai bersama". (Pidato Kenegaraan, 16 Agustus 2006).

"Mari kita bangun budaya demokrasi yang konstruktif, dengan, antara lain membangun suasana kompetisi yang sehat, jujur, dan kesatria. Marilah sama-sama kita menghormati mereka yang menang maupun yang kalah. Dalam demokrasi, kalah dan menang adalah biasa. Dua-duanya terhormat dan mulia". (Keterangan Pemerintah, 23 Agustus 2006).

"Mari kita bangun kehidupan berbangsa dan bernegara secara sehat. Mari kita bangun hubungan kelembagaan lebih erat lagi. Sebagai kepala negara, saya mengajak Dewan Perwakilan Rakyat, Dewan Perwakilan Daerah, Mahkamah Agung, Mahkamah Konstitusi, dan lembaga-lembaga negara lainnya untuk bersinergi satu sama lain secara lebih solid, sesuai dengan beban yang diamanahkan oleh konstitusi dan perundang-undangan kepada kita semua". (Pidato Presiden, 16 Agustus 2007).

"Dalam melaksanakan pembangunan nasional di tahun 2008 yang akan datang, marilah kita kelola segala daya dan kemampuan yang ada, termasuk kebijakan fiskal kita, secara efisien dan efektif, agar hasilhasil pembangunan nasional benarbenar dapat dinikmati oleh seluruh rakyat. Marilah kita tingkatkan semangat juang bangsa kita, mewujudkan agenda-agenda pembangunan berkelanjutan bagi keamanan, kedamaian, keadilan, dan kesejahteraan rakyat di seluruh persada nusantara". (Pidato Presiden, 16 Agustus 2007).

"Bangsa kita memiliki kemampuan dan bisa mengubah nasib dan masa depan kita, serta bisa menjadi negara maju, unggul dan sejahtera. 
Oleh karena itu, saya mengajak saudara-saudara, marilah kita terus berjuang bersama, melangkah bersama, dan bekerja keras bersama, untuk meraih masa depan Indonesia yang gemilang". (Sambutan Presiden, 20 Mei 2008).

\section{Pemakaian Kalimat Seruan}

Kalimat seruan dipakai oleh Presiden Susilo Bambang Yudhoyono dalam wacana politik dengan tujuan agar rakyat melakukan apa yang diserukan, baik berupa tindakan maupun sikap. Dibandingkan dengan ajakan, kalimat seruan ini terkesan ada jarak antara "atasan" dan 'bawahan", antara penguasa dan rakyat. Oleh karena itu, dengan penggunaan kalimat seruan ini Presiden Susilo Bambang Yudhoyono menyadari kedudukannya sebagai pengatur atas bawahannya, dan sebagai penguasa atas rakyatnya.

Dilihat dari isinya, yang diserukan adalah perihal antisipasi dari kasuskasus yang sedang menjadi isu sentral dan yang meresahkan rakyat, misalnya kasus krisis ekonomi yang sedang melanda rakyat, krisis politik yang berkepanjangan, adanya tindakan anarkis yang terjadi dimana-mana, munculnya konflik horizontal yang mudah muncul, dan sebagainya. Apabila seruan ini dilakukan secara patuh oleh rakyat, minimal kasus-kasus tersebut bisa diredam atau bisa diatasi. Contoh kutipan berikut menunjukkan bagaimana Presiden Susilo Bambang Yudhoyono mengungkapkan kalimat seruan dalam bentuk himbauan dan peringatan.

"Dalam berbagai rapat koordinasi dengan Pemerintah Daerah, saya telah berulangkali meminta, agar daerah-daerah menciptakan iklim investasi dan iklim berusaha yang sehat di daerahnya. Berbagai peraturan daerah yang tumpang tin- dih dan menghambat investasi, perlu diperbaiki. Demikian pula pelayanan birokrasi, terutama yang berkaitan dengan perizinan. Untuk kesekian kalinya saya sampaikan, "permudahlah setiap urusan". Jangan mempersulit sesuatu, yang sesungguhnya dapat dilakukan dengan mudah". (Keterangan Pemerintah, 23 Agustus 2006).

"Ke depan, kita harus menyusun strategi pertumbuhan antarkawasan yang bersifat sinergis dan terintegrasi. Dengan demikian, pertumbuhan yang signifikan di suatu daerah, akan merangsang percepatan pertumbuhan daerah di sekitarnya". (Keterangan Pemerintah, 23 Agustus 2006).

"Adalah wajar apabila masih dijumpai ketegangan dan kesalahpahaman di antara pihak-pihak yang dulunya bersengketa lebih dari 30 tahun, karena memang upaya untuk membangun rasa saling percaya (Trust Building) sedang terus kita laksanakan. Semua pihak, terutama pemerintahan di Aceh sendiri harus terus mengawal, mengamankan dan menyukseskan proses reintegrasi ini, seiring dengan upaya membangun kembali Aceh pasca tsunami, menuju ke kondisi ekonomi dan kesejahteraan masyarakat yang lebih baik". (Pidato Presiden, 16 Agustus 2007).

\section{"Kita juga harus tegar dan} lentur menghadapi arus sejarah baru yang sangat dahsyat dan tidak dapat kita hindari: yakni globalisasi, dengan segala dampak positif dan negatifnya. Bangsa kita tidak boleh terlindas oleh gelombang sejarah ini. Sebaliknya, bangsa kita harus dapat memanfaatkan dan meraih berbagai peluang yang timbul dari globalisasi. 
Untuk itu, kita harus menjadi bangsa yang unggul, bangsa yang berdayasaing tinggi, bangsa yang inovatif dan kreatif. Bangsa kita juga harus kembali berada di garis terdepan dalam upaya membangun kemitraan global (global partnership) . Kemitraan global ini mutlak diperlukan, agar umat manusia dapat keluar dari berbagai tantangan yang silih berganti: kesenjangan, kemiskinan, ketidakadilan, penindasan, konflik, bencana alam, penyakit menular, terorisme, perubahan iklim, dan lain sebagainya". (Pidato Presiden, 16 Agustus 2007).

"Tantangan yang kita hadapi untuk mencapai tujuan mulia ini, memang lebih berat dan lebih kompleks dari tantangan yang kita hadapi di masa lalu. Oleh karena itu, untuk menjadi bangsa yang berhasil, ada tiga syarat fundamental yang harus kita bangun dan miliki, yaitu: Pertama, kita harus menjaga dan memperkuat kemandirian kita, Kedua, kita juga harus memiliki daya saing yang makin tinggi. Persyaratan fundamental yang ketiga adalah, kita harus mampu membangun dan memiliki peradaban bangsa (civilization) yang mulia. Itulah sebabnya, kita perlu terus mempertahankan nilai, jati diri dan karakter bangsa kita yang luhur dan terhormat". (Sambutan Presiden, 20 Mei 2008).

"Kepada masyarakat dunia, saya juga menyerukan dan mengajak untuk bersama-sama mewujudkan tatanan dunia yang lebih damai, lebih adil, dan benar-benar membawa kemakmuran bagi semua bangsa, dan bukan hanya bagi segelintir bangsa. Keadilan sejati pada tingkat dunia harus dapat kita wujudkan". (Sambutan Presiden, 20 Mei 2008).

\section{Pemakaian Kalimat Harapan}

Hampir sama dengan kalimat seruan, kalimat harapan dipakai oleh Presiden Susilo Bambang Yudhoyono dalam wacana politik dengan tujuan agar rakyat atau komponen tertentu dari rakyat bisa melakukan tindakan atau sikap sesuai dengan yang diinginkan. Apabila dalam kalimat seruan ada nuansa atasbawah, dalam kalimat harapan ada nuansa kesetaraan. Oleh karena itu, nuansa paksaan tidak terasa dalam kalimat harapan ini. Kalimat jenis ini dipakai Presiden Susilo Bambang Yudhoyono karena ia merasa tidak mempunyai otoritas atau kekuasaan penuh untuk "memaksakan" apa yang diinginkan. Sebaliknya, pihak sasaranlah (rakyat, publik) yang mempunyai otoritas melakukannya. Kutipan berikut menunjukkan sinyalmen itu.

"Mudah-mudahan, hubungan kemitraan yang konstruktif dan bertanggung jawab ini, dapat kita tingkatkan lagi di waktu-waktu yang akan datang". (Keterangan pemerintah, 23 Agustus 2006).

"Dalam perjalanan selama satu tahun ke depan ini, saya mengharapkan meningkatnya hubungan yang lebih konstruktif antara Pemerintah dengan Dewan Perwakilan Daerah. Dalam mencapai tujuan negara yang diamanatkan di dalam Pembukaan Undang-Undang Dasar, saya mengharapkan agar Dewan Perwakilan Daerah dapat menjalankan peran dan fungsinya secara konstruktif, dalam rangka mempercepat terwujudnya kesejahteraan rakyat di daerah, dalam koridor Negara Kesatuan Republik Indonesia, yang berdasarkan Pancasila". (Keterangan pemerintah, 23 Agustus 2006).

"Tentu saya sangat berharap, agar ketiga RUU itu dapat juga dise- 
lesaikan dalam waktu yang cukup singkat, sehingga memberikan kepastian dan perbaikan dalam lingkungan usaha". (Pidato Presiden, 16 Agustus 2007).

"Kita berharap, bahwa langkah-langkah yang dilakukan oleh otoritas-otoritas keuangan di negara maju, dapat segera meredam gejolak ini. Kita di sini, juga melakukan langkah-langkah antisipatif dengan memperkuat koordinasi kebijakan antara otoritas fiskal dan otoritas moneter, untuk meningkatkan kesiagaan kita". (Pidato Presiden, 16 Agustus 2007).

\section{Pemakaian Kalimat Janji}

Kalimat janji dipakai oleh Presiden Susilo Bambang Yudhoyono dalam wacana politik dengan tujuan memberikan harapan kepada rakyat atas tindakan atau sikap yang akan ditempuh. Dengan kalimat janji ini, rakyat akan mengetahui target atau langkah apa yang akan dilakukan Presiden Susilo Bambang Yudhoyono berkaitan dengan isu-isu yang sedang menghangat. Konsekuensinya adalah rakyat akan terus memantau, bahkan melakukan kontrol, atas janji yang pernah diungkapkan Presiden Susilo Bambang Yudhoyono. Dalam posisi demikian, beban Presiden Susilo Bambang Yudyono tentu akan lebih berat bila dibandingkan dengan tanpa menggunakan kalimat janji.

Pada pihak Presiden Susilo Bambang Yudhoyono, walaupun yang dijanjikan belum dilaksanakan, keuntungan yang segera bisa diperoleh dengan pengungkapan kalimat janji adalah bisa segera memunculkan "rasa lega" rakyat atau sasaran yang terlibat. Sebab dengan janji-janji yang diberikan, rakyat akan segera membayangkan tindakan riil dari pihak Presiden Susilo Bambang Yudhoyono sesuai dengan yang dijanji- kan walaupun, sebagian rakyat juga menyadari bahwa tidak semua janji bisa dilaksanakan. Kutipan berikut menunjukkan fenomena tersebut.

"Pemerintah memiliki komitmen yang tinggi untuk meningkatkan kesejahteraan rakyat di kawasan-kawasan yang tertinggal itu". (Keterangan pemerintah, 23 Agustus 2006).

"Dalam bagian akhir ini, saya ingin menegaskan kembali komitmen saya untuk memberantas korupsi. (Keterangan Pemerintah, 23 Agustus 2006).

Bagi Pegawai Negeri Sipil dan anggota TNI/Polri, secara bertahap, kita naikkan penghasilannya. Bagi masyarakat, kita upayakan memperingan pengeluarannya. Sebagai contoh, dalam bidang pendidikan, pemerintah terus meningkatkan anggaran pendidikan dari tahun ke tahun. Kita ingin, pendidikan yang bermutu dapat dinikmati oleh seluruh anak-anak kita. (Pidato Presiden, 16 Agustus 2007).

Kita sungguh serius untuk mencegah dan menanggulangi terorisme ini, karena kita ingin menyelamatkan masyarakat dan bangsa kita, menghadirkan keamanan dan ketentraman di negeri kita, dan sekaligus sebagai tanggung jawab dan kebersamaan kita dengan masyarakat global untuk menciptakan dunia yang aman dan damai". (Pidato Presiden, 16 Agustus 2007).

"Peningkatan akses dan perluasan pemerataan pendidikan juga dilakukan dengan penyediaan sarana dan prasarana terutama untuk wilayah pedesaan dan terpencil. 
Pemberian beasiswa bagi siswa miskin di berbagai jenjang pendidikan akan terus ditingkatkan". (Pidato Presiden, 16 Agustus 2007).

\section{Pemakaian Kalimat Pernyataan}

Kalimat pernyataan dipakai oleh Presiden Susilo Bambang Yudhoyono dalam wacana pidato dengan tujuan menunjukkan sikap atau pendiriannya kepada rakyat atas isu-isu yang sedang berkembang atau permasalahan yang sedang dihadapi. Lewat kalimat pernyataan ini, rakyat bisa mengukur kadar kepekaan presiden atas isu yang sedang berkembang. Pada sisi lain, rakyat juga bisa membandingkan kesesuaian sikap presiden dengan opini massa yang sedang berkembang. Apabila sesuai, tentu Presiden Susilo Bambang Yudhoyono akan mendapatkan dukungan. Sebaliknya, apabila tidak sesuai atau bertolak belakang, tentu ia akan mendapatkan tantangan. Penilaian rakyat akan berlanjut dengan melihat lebih jauh apakah pernyataan sikap presiden ini sesuai dengan tindakan nyata yang telah dan sedang dilakukan. Pernyataan sikap yang sesuai dengan tindakan akan mendapatkan respons positif dari rakyat. Sebaliknya, pernyataan sikap yang berseberangan dengan tindakan tentu tidak akan mendapatkan perhatian rakyat. Sebab, pernyataan sikap semacam itu dinilainya sebagai upaya mencari pembenaran dan dukungan rakyat saja. Kutipan berikut membuktikannya.

"Pemerintah akan terus menyempurnakan sistem perlindungan bagi keluarga miskin. Seperti telah saya uraikan di muka, sejak tahun 2005 lalu, dari hasil penghematan subsidi BBM, kita telah berhasil memperkenalkan program yang langsung menyentuh rakyat miskin, seperti sistem asuransi kesehatan untuk rumah tangga miskin dan Subsidi Langsung
Tunai (SLT), Bantuan Operasional Sekolah atau BOS, dan pembangunan infrastruktur perdesaan. Program ini akan dilanjutkan pada tahun 2007 dengan beberapa perbaikan, seperti Bantuan Langsung Tunai Bersyarat untuk menunjang perbaikan akses pendidikan dan kesehatan keluarga miskin, dan program padat karya di tingkat desa yang dapat menciptakan lapangan kerja". (Pidato Kenegaraan, 16 Agustus 2006).

"Dalam penanganan lumpur di Sidoarjo, sejak awal telah kita upayakan. Pemerintah tidak tinggal diam. Pemerintah telah membentuk Badan Pelaksana Penanggulangan Lumpur Sidoarjo (BP2LS). Kita tidak dapat membiarkan rakyat terus menderita. Kita harus secepatnya meringankan penderitaan rakyat dengan penuh kesungguhan. $\mathbf{P e}$ merintah menaruh perhatian yang sungguh-sungguh terhadap masalah ini. Pemerintah akan memastikan pembayaran sisanya akan dilakukan sesuai ketetapan yang disepakati dalam Perpres 14 Tahun 2007. (Pidato Presiden, 16 Agustus 2007).

"Kita sepakat bahwa kesejahteraan rakyat merupakan muara dari semua agenda pembangunan yang dilaksanakan. Pemerintah terus melakukan program-program prorakyat. (Pidato Presiden, 16 Agustus 2007).

"Sebagaimana sering saya sampaikan, kedepan, kita tidak boleh hanya menangani terorisme yang berada di permukaan, tetapi harus harus kita sentuh dan atasi akar penyebabnya, seperti keterbelakangan, kemiskinan, ketidakadilan, ekstrimitas, radikalitas dan budaya ke- 
kerasan. (Pidato Presiden, 16 Agustus 2007).

"Demikian pula di tanah Papua, kita terus melakukan percepatan pembangunan untuk meningkatkan kesejahteraan Masyarakat Papua dan Papua Barat. Menandai keseriusan Pemerintah untuk segera dapat meningkatkan kesejahteraan masyarakat kedua provinsi tersebut, saya telah mengeluarkan Inpres Nomor 5 Tahun 2007 tentang Percepatan Pembangunan Provinsi Papua dan Provinsi Papua Barat. Prioritas pembangunan ini terutama ditujukan pada pemantapan ketahanan pangan dan pemberdayaan ekonomi masyarakat, pelayanan pendidikan dan kesehatan yang berkualitas, peningkatan infrastruktur dasar untuk pengembangan wilayah potensial, serta kebijakan khusus bagi putra-putri Papua". (Pidato Presiden, 16 Agustus 2007).

\section{Pemakaian Gaya Bahasa}

Gaya bahasa merupakan cara untuk mengungkapkan ide atau pendapat lewat wacana verbal. Oleh karena itu, gaya bahasa sangat terkait dengan aspek-aspek kebahasaan, mulai dari pilihan kata, pembentukan kata, pembentukan kalimat, dan penataan kalimat dalam suatu wacana. Lewat penggunaan gaya bahasa tertentu penutur ingin memberikan tekanan tertentu atas isi wacana yang disampaikan agar penerima tutur dapat memahaminya dengan efektif.

Wacana pidato yang diungkapkan Presiden Susilo Bambang Yudhoyono juga mengandung pemakaian gaya bahasa tertentu. Berdasarkan data yang terhimpun, wacana pidato Presiden Susilo Bambang Yudyono menggunakan paling sedikit lima jenis gaya bahasa, yaitu (a) eufemisme, (b) pleonasme, (c) hiperbola, (d) pararelisme, dan (e) repetisi.

\section{Pemakaian Eufimisme}

Gaya eufimisme dipakai Presiden Susilo Bambang Yudhoyono ketika ingin menghaluskan makna dalam wacana politiknya. Penghalusan makna ini dilakukan dengan cara memilih kata atau istilah yang mempunyai konotasi sopan, menyenangkan, tidak menyinggung perasaan, tidak menghina, dan konotasi positif lainnya. Dengan menggunakan gaya bahasa jenis ini Presiden Susilo Bambang Yudhoyono ingin menunjukkan kepada rakyat bahwa ia sebagai figur yang sopan, rendah hati, dan tidak menonjolkan kekuasannya. Kesan semacam ini memang perlu dimunculkan agar ia dapat simpati dari rakyat. Fenomena ini terlihat pada kutipan ini.

"Pemerintah selalu terbuka untuk bekerjasama lebih baik. Termasuk membuka diri bagi munculnya gagasan-gagasan baru, untuk penyempurnaan tata hubungan kelembagaan kita". (Pidato Presiden, 16 Agustus 2007).

\section{Pemakaian Pleonasme}

Gaya pleonasme dipakai Presiden Susilo Bambang Yudhoyono ketika ingin menonjolkan bagian tertentu pada wacana pidatonya. Penonjolan ini dimaksudkan agar penerima tutur atau rakyat mendapatkan perhatian khusus atas bagian yang dianggap penting oleh Presiden Susilo Bambang Yudhoyono. Cara yang biasa dilakukan adalah memberikan pengulangan arti yang sama atau hampir sama dengan kata-kata yang berbeda. Kutipan berikut menunjukkan betapa Presiden Susilo Bambang Yudhoyono terbiasa menggunakan gaya pleonasme tersebut. 
"Negara kita memiliki berbagai sumber energi alternatif dalam jumlah yang cukup besar seperti gas, batubara, tenaga hidro, panas bumi, tenaga surya dan lainnya. Investasi di bidang itu masih perlu dikembangkan". (Pidato Kenegaraan, 16 Agustus 2006).

"Sementara itu, pada kurun waktu yang sama, anggaran Departemen Kesehatan melonjak hampir tiga kali lipat dari Rp.6,5 triliun menjadi Rp.18,8 triliun, terutama untuk pelayanan kesehatan bagi masyarakat miskin, penanggulangan penyakit menular, penanganan masalah gizi kurang, penyediaan obat esensial generik, pelayanan kesehatan bagi ibu dan anak, serta penyediaan tenaga kesehatan". (Pidato Presiden, 16 Agustus 2007).

"Dalam kurun tiga tahun terakhir, kondisi yang kita hadapi memang penuh tantangan. Berbagai bencana alam seperti tsunami, gempa bumi, tanah longsor, dan bencana banjir telah menyebabkan jatuhnya korban dan kerusakan material. (Pidato Presiden, 16 Agustus 2007).

\section{Pemakaian Hiperbola}

Gaya hiperbola dipakai Presiden Susilo Bambang Yudhoyono ketika ingin menonjolkan bagian tertentu dalam wacana yang diungkapkan. Hanya saja, penonjolan bagian tertentu dalam wacana yang diungkapkan. Hanya saja, penonjolan bagian tertentu ini tidak dilakukan dengan cara memberikan pengulangan arti sebagaimana dalam gaya pleonasme, tetapi dengan cara memilih kata tertentu yang dianggap mempunyai nuansa 'lebih' dari pada kenyataan yang ada. Maksud penggunaan gaya ini agar penerima tutur atau rakyat bisa lebih menghayati yang disampaikan Presiden
Susilo Bambang Yudhoyono dalam wacana politiknya, atau bahkan melibatkan emosi dalam penghayatannya. Contoh berikut menunjukkan fenomena itu.

"Rakyat kita seakan-akan kehilangan pegangan, dan kehilangan jati diri sebagai sebuah bangsa yang bermartabat". (Pidato Presiden, 16 Agustus 2007).

\section{Pemakaian Paralelisme}

Berbeda dengan gaya bahasagaya bahasa sebelumnya yang menitikberatkan unsur makna, gaya pararelisme lebih menitikberatkan pada unsur struktur bahasa. Gaya pararelisme ini menggunakan kesejajaran bentuk ketika mengespresikan gagasan dalam wacananya. Unsur yang disejajarkan ini bisa berupa kata, frase atau klausa. Penentuan unsur mana yang disejajarkan sangat bergantung pada kepentingannya. Disamping itu, unsur-unsur yang disejajarkan harus berkedudukan pararel dari segi gramatika.

Penggunaan gaya pararelisme ini nampak ketika Presiden Susilo Bambang Yudhoyono ingin memberikan klasifikasi atau memberikan detil suatu gagasan yang diugkapkannya. Dengan menggunakan gaya jenis ini Presiden Susilo Bambang Yudhoyono ingin agar gagasaan dalam wacana politiknya dapat dipahami dan diterima dengan baik oleh penerima tutur atau rakyat. Berikut ini contoh pemakaian gaya pararelisme yang terdapat dalam wacana pidato Presiden Susilo Bambang Yudhoyono, berdasarkan klasifikasinya.

"Kemitraan global ini mutlak diperlukan, agar umat manusia dapat keluar dari berbagai tantangan yang silih berganti: kesenjangan, kemiskinan, ketidak-adilan, penindasan, konflik, bencana alam, penyakit menular, terorisme, perubahan 
iklim, dan lain sebagainya". (Pidato Presiden, 16 Agustus 2007).

"Marilah kita tingkatkan semangat juang bangsa kita, mewujudkan agenda-agenda pembangunan berkelanjutan bagi keamanan, kedamaian, keadilan, dan kesejahteraan rakyat di seluruh persada nusantara". (Pidato Presiden, 16 Agustus 2007).

"Sebagaimana sering saya sampaikan, kedepan, kita tidak boleh hanya menangani terorisme yang berada di permukaan, tetapi harus harus kita sentuh dan atasi akar penyebabnya, seperti keterbelakangan, kemiskinan, ketidakadilan, ekstrimitas, radikalitas dan budaya kekerasan". (Pidato Presiden, 16 Agustus 2007).

\section{Pemakaian Repetisi}

Apabila gaya pararelisme melakukan ekspresi kebahasaan dengan cara menyejajarkan unsur-unsur kebahasaan yang berkedudukan pararel, gaya repetisi dengan cara mengulang unsur-unsur kebahasaan tertentu karena dirasa perlu mendapatkan penekanan. Yang diulang bisa berupa kata, frase, atau klausa.

Wacana pidato Presiden Susilo Bambang Yudhoyono juga menggunakan gaya repetisi. Bahkan, penggunaan gaya jenis ini menduduki urutan kedua setelah gaya pararelisme. Gaya ini dimaksudkan Presiden Susilo Bambang Yudhoyono agar bagian-bagain tertentu yang diulang mendapatkan perhatian ekstra dari penerima tutur atau rakyat. Secara teknis, pengulangan ini tidak harus sama secara redaksional, tetapi sering dilakukan secara bervariasi. Hal ini dimaksudkan selain agar menghilangkan rasa monoton, juga agar bisa menimbulkan efek tertentu dari penerima tutur. Berikut ini contoh pemakai- an gaya repetisi berdasarkan klasifikasi yang dimaksud.

"Saudara ikut mengharumkan nama bangsa kita. Mahal harga diri dan kehormatan sebuah bangsa. Dengan tampilan saudara, perilaku saudara, kinerja saudara, prestasi saudara, kami bangga. Pertahankan itu dan teruskan untuk lebih mengharumkan lagi nama bangsa dan negara kita". (Sambutan Presiden, 2 Mei 2006).

"Kita mendayagunakan yang kita miliki: kemampuan dalam negeri, sumber finansial dalam negeri, usaha dalam negeri, teknologi kita, pendidikan kita, tetapi dalam era globalisasi ini, tidak ada satu negara pun yang tidak bekerja sama dengan negara lain. (Sambutan Presiden, 2 Mei 2006).

"Dialog-dialog itu, tidak saja dilakukan secara formal, tetapi juga secara informal dan penuh persaudaraan, dengan mengajak tokoh-tokoh masyarakat, tokoh-tokoh adat, tokoh-tokoh agama, dan tokoh-tokoh perempuan". (Keterangan Pemerintah, 23 Agustus 2006).

\section{SIMPULAN}

Dari temuan dan bahasan di atas dapat disimpulkan bahwa strategi politik penggunaan bahasa dalam pidato Presiden Susilo Bambang Yudhoyono, dalam tataran penggunaan kata, unsur yang tampak adalah penggunaan katakata persona, penggunaan kata yang bernuansa "reformasi", dan "keterbukaan". Ketiga hal yang hampir menyebar ke semua wacana pidato Presiden Susilo Bambang Yudhoyono ini disampaikannya dengan maksud dan tujuan yang berbeda. Kata persona digunakan Presiden Susilo Bambang Yudhoyono 
sebagai alat untuk menunjukkan posisinya dalam wacana politik yang dibangunnya. Dari data verbal yang terkumpul, Presiden Susilo Bambang Yudhoyono menggunakan kata persona saya, kami, kita, bangsa Indonesia, Indonesia, dan pemerintah.

Wacana verbal dalam pidato yang diungkapkan Presiden Susilo Bambang Yudhoyono diekspresikan dalam bentuk rangkaian kalimat. Dari segi maksudnya, kalimat-kalimat yang diekspresikan Presiden Susilo Bambang Yudhoyono ada yang berbentuk kalimat ajakan, kalimat seruan, kalimat harapan, kalimat janji, dan kalimat pernyataan. Pemakaian berbagai jenis maksud kalimat ini disesuaikan dengan tujuan yang ingin dicapai dan jenis tema yang dilontarkannya.

Wacana pidato yang diungkapkan Presiden Susilo Bambang Yudhoyono juga mengandung pemakaian gaya bahasa tertentu. Berdasarkan data yang terhimpun, wacana pidato Presiden Susilo Bambang Yudhoyono menggunakan paling sedikit lima jenis gaya bahasa, yaitu eufemisme, pleonasme, hiperbola, pararelisme, dan repetisi.

\section{UCAPAN TERIMA KASIH}

Artikel ini diangkat dari penelitian mandiri swadana yang dilaksanakan pada tahun 2009. Ucapan terima kasih disampaikan kepada mitra sejawat yang telah membantu kegiatan verifikasi dan triangulasi data dan hasil penelitian. Ucapan terima kasih juga disampaikan kepada Prof. Dr. Suparno selaku pengampu mata kuliah Kajian Wacana di Program Pascasarjana Universitas Negeri Malang yang telah memberi arahan, bimbingan aspek-aspek teroritik dalam kaitannya dengan kajian wacana.

\section{DAFTAR RUJUKAN}

Fairclough, N. 1989. Language and Power. New York: Longman.

Fairclough, N. 1995. Critical Discourse Analysis: The Critical Study of Language. London and New York: Longman.

Fairclough, N. 1995. Media Discourse. London : Edward Arnold.

Fairclough, N. 1998. "Political Discourse in the Media". Dalam A. Bell dan P. Garret (ed.) Media Discourse. Oxford : Black well Publisher Inc.

Faoucault, M. 1977. Languge, CounterMemory, Practice: Selected Essays and Interviews. Ithaca : Cornell University Press.

Keterangan Pemerintah tentang Kebijakan Pembangunan Daerah di Depan Sidang Paripurna DPD-RI. Jakarta, 23 Agustus 2006. http://www. presidenri.go.id/ index.php/pidato/2006/08/23/429.html. Diakses 24 April 2008

Pidato Kenegaraan Presiden Republik Indonesia Serta Keterangan Pemerintah Atas Rancangan Undang-Undang Tentang Anggaran Pendapatan Dan Belanja Negara Tahun Anggaran 2007 Beserta Nota Keuangannya Di Depan Rapat Paripurna Dewan Perwakilan Rakyat Republik Indonesia. Jakarta, 16 Agustus 2006. Http:// Www.Presidensby.Info/Index. Php/Pidato/2006/08/16/423.Html. Diakses 24 April 2008.

Pidato Presiden Ri (Dr. Haji. Susilo Bambang Yudhoyono). Jakarta, 16 Agustus 2007. Http://Terbangkelangit. Multiply.Com/Journal/Item/54/ Pidato Presiden Ri Dr. Haji. Susilo Bambang Yudhoyono. Diakses 24 April 2008.

Remlinger, K. 1999. Widening the Lens of Language and Gender Research; Integrating Critical Discourse Analysis and Cultural Practice 
Theory. Linguistik Online, 2 no1, (http://www.linguistik-online.de/ helfl 99/remlinger.hatm).

Sahpiro, M.J. 1984. Language and Politics. New York “ New York University Press.

Sambutan Presiden Susilo Bambang Yudhoyono Dalam Pertemuan Dengan Masyarakat Indonesia Wisma Duta, Abu Dhabi. Abu Dhabi. 2 Mei 2006. Http://Www.Presidensby.Info/Index.Php/Pidato/2006/05/02/245. Html. Diakses 24 April 2008
Sambutan Presiden Republik Indonesia Pada Peringatan 100 Tahun Kebangkitan Nasional Tahun 2008. Jakarta, 20 Mei 2008. http://www.presidensby.info/ index.php/pidato/2008/05/20/907.html. Diakses 21 Mei 2008

Van Dijk, TA. 1985. Handbook of Discourse Analysis : Discourse Analysis ini Society. Vol. 4 London : Academic Press, Inc. 